\title{
Bahman Kargar, Ali Binandeh. A Preliminary Report of Excavations at Rabat Tepe, Northwestern Iran
}

\section{Rémy Boucharlat}

\section{(2) OpenEdition \\ 1 Journals}

\section{Édition électronique}

URL : http://journals.openedition.org/abstractairanica/40344

DOI : 10.4000/abstractairanica.40344

ISSN : 1961-960X

Éditeur :

CNRS (UMR 7528 Mondes iraniens et indiens), Éditions de l'IFRI

\section{Édition imprimée}

Date de publication : 1 décembre 2013

ISSN : 0240-8910

\section{Référence électronique}

Rémy Boucharlat, «Bahman Kargar, Ali Binandeh. A Preliminary Report of Excavations at Rabat Tepe, Northwestern Iran », Abstracta Iranica [En ligne], Volume 32-33 | 2013, document 87, mis en ligne le 01 juillet 2016, consulté le 05 octobre 2020. URL : http://journals.openedition.org/abstractairanica/40344 ; DOI : https://doi.org/10.4000/abstractairanica.40344

Ce document a été généré automatiquement le 5 octobre 2020.

Tous droits réservés 


\title{
Bahman Kargar, Ali Binandeh. A Preliminary Report of Excavations at Rabat Tepe, Northwestern Iran
}

\author{
Rémy Boucharlat
}

\section{RÉFÉRENCE}

Bahman Kargar, Ali Binandeh. « A Preliminary Report of Excavations at Rabat Tepe, Northwestern Iran ». Iranica Antiqua, 45, 2009, p. 113-130, 14 Pl. coul.

1 Très brève présentation, mais bien illustrée, d'éléments architecturaux découverts en fouille sur le gros tépé de Rabat au Kurdistan, à environ $90 \mathrm{~km}$ à l'ouest de Ziwiye. Ces documents appartiennent à la période I des fouilleurs qui date de la même période que Ziwiye, Bukan ou Hasanlu IIIA, soit les VIII ${ }^{\mathrm{e}-\mathrm{VII}}{ }^{\mathrm{e}}$ s. av. J.-C., et ils sont attribués aux Mannéens. Ces éléments sont des sols de galets dessinant d'étonnants cercles concentriques, et une série de briques à glaçure portant des représentations très comparables à celles de Qalaichi, près de Bukan, situé plus au nord (cf. Abs. Ir. 30, c.r. $n^{\circ} 37$, où fut trouvée également, mais hors fouille une inscription araméenne aujourd'hui célèbre (cf. Abs. Ir. 22, c.r. n 142-144). On retrouve à Rabat Tepe motifs floraux, lion ailé à tête d'homme, personnages. 


\section{AUTEURS}

RÉMY BOUCHARLAT

CNRS, Lyon 